\title{
Quantitative Assessments of Textiles Trade Liberalization: A Survey
}

\author{
Peter Walkenhorst \\ $O E C D$
}

\begin{abstract}
Available quantitative studies on the effects of textiles market liberalization consistently indicate considerable shifts in production and trade, with output expanding particularly in Asian developing countries and contracting in industrialized countries. Even though all the reviewed studies foresee increases in global welfare as a result of liberalization, there is considerable variation in the magnitude of expected benefits and their distribution. This survey discusses the available assessments and highlights the differences in analytical approaches and data that trigger the variation in results.
\end{abstract}

- JEL Classification: F14, L67, D67

- Key words: Trade liberalization, Agreement on Textiles and Clothing; General equilibrium modeling

\section{Background}

On 1 January 1995, the WTO Agreement on Textiles and Clothing (ATC) came into force, which sets out a process to integrate trade in textiles and clothing into the general GATT framework. It is a transitional arrangement that is scheduled to lead to the application of normal GATT rules to the sector starting on 1 January 2005. From 1974 to 1994, trade in textiles and clothing was governed by the Multifibre Arrangement (MFA), which provided for the application of selective

\footnotetext{
*Corresponding address: Organisation for Economic Co-operation and Development, 2 rue André-Pascal, 75775 Paris Cedex 16, France [Phone: +33 14524 8934; Email: Peter.Walkenhorst@oecd.org]. The views expressed in the paper are the authors and do not necessarily reflect those of the OECD or its Member countries.

(C)2005-Center for International Economics, Sejong Institution, All Rights Reserved.
} 
bilateral quotas when surges in imports of particular products caused, or threatened to cause, serious damage to the industry of the importing country. The MFA was a major departure from basic GATT rules and, in particular, the principle of nondiscrimination. The ATC replaces the MFA and commits WTO members to reduce import tariffs, progressively integrate parts of their textile imports into the GATT framework, and enlarge remaining quotas (until they are removed) by increasing annual growth rates at subsequent liberalization stages.

There is a considerable body of analysis available that aims to quantify the economic and trade effects of textiles and clothing market liberalization. A number of analysts at national and international institutions have provided their assessments. Different tools and approaches have thereby been used to evaluate the impacts of textiles trade reform at the regional or global level. Given the economic importance of the textiles and clothing sector in a number of countries and the resulting economy-wide repercussions that changes in the scale and pattern of textiles production will tend to trigger, analysis using general equilibrium models has been dominant, even though in some cases partial equilibrium approaches have been pursued (e.g. Yang, 1994). Most of this research has been published during the 1990s, and the following review compares the findings of pertinent quantitative studies that have aimed to analyze the world-wide effects of MFA phase-out. ${ }^{1}$ Moreover, references to pre-1990 analysis that has aimed to assess the effects of liberalizing textiles and clothing trade can be found, for example, in Pelzman (1983), Goto (1989) and Spinanger (1991).

Reviewing quantitative assessments of textiles market liberalisation just before the final ATC integration stage is completed seems timely in terms of providing policy makers with an overview of existing studies and analysts with a guide to unresolved issues. The integration of MFA quotas has been backloaded and it is generally expected that the major economic and trade effects will only occur after the end of the transition period. In this context, the following discussion aims to review the likely economic impacts of ATC reform and survey available estimates of the overall and relative magnitude of different economic effects. In particular, the analysis highlights the ranges of world-wide welfare impacts found in the

There are also a number of studies, including De Melo and Tarr (1990), Elbehri et al. (2003), Francois et al. (2000), Francois and Spinanger (2002), Hanson and Reinert (1997), Ianchovina et al. (2000), Reinert (1993), Schöppenau et al. (2002), Walmsley and Hertel (2000), and Yang and Zhong (1998), that have quantified the implications of MFA phase-out for particular countries. See chapter 4 of OECD (2003) for a summary and discussion. 
literature.

The remainder of the study is organized in three parts. Section 2 provides background information for the subsequent literature review by discussing some of the major economic and trade effects that could be expected from ATC reform. Section 3 then summarizes and reviews quantitative studies that have assessed the world-wide effects of ATC reform. Finally, section 5 briefly summaries the main observations, discusses policy implications, and points to issues that might warrant further analysis.

\section{The Economics of Trade Liberalization in the Textiles and Clothing Sector}

Under the MFA, developed and developing countries negotiated bilateral quotas regulating trade in textiles and clothing. In order to implement these quantitative restrictions, it was agreed that exporting developing countries would voluntarily restrain their supplies. Export rights became scarce and turned into valuable assets, generating rents for internationally competitive suppliers. Governments generally distributed the quotas free of charge to domestic firms based on criteria such as past export performance (Hamilton, 1990). In most countries, quotas were not tradable. Such allocation schemes favoring status-quo exporters, as well as requirements that, for example, related annual quota renewal to export performance in unrestricted markets, generated substantial efficiency losses in developing countries over time (Trela and Whalley, 1995). In some cases, developing country exporters had to share parts of their quota rents with importing firms that were able to exercise market power at the individual product level (Krishna, Erzan and Tan, 1994). Yet, it seems reasonable to assume that most of the rents generated under the MFA accrued to developing country exporters.

The system of bilateral quotas has frequently been accompanied by high tariffs applied on imports of textiles and clothing. Countries engaged in tariff reduction commitments during the Uruguay Round, but tariffs on textiles and clothing frequently remain significant even after the cuts, and are on average considerably higher than in the manufacturing sector overall. Also, textiles and clothing tariffs appear to be consistently high across a large number of products and show lower than average variation. Moreover, high tariffs on textiles and clothing exports are not confined to OECD countries. Large developing country exporters, like ASEAN, China, and South Asia have tariffs ranging from 20 to 33 per cent on textiles and 
30 to 35 per cent on clothing, impeding the increasingly important trade among developing countries (Lankes, 2002).

Tariffs and quotas interact in multiple ways, depending on the size of the tariff barriers and the restrictiveness of the quotas. If tariffs are very high, import demand will be low and the quotas will not be binding and, hence, not generate any quota rents. If, however, quotas are binding, tariffs are not affecting import demand, but merely generate transfers to the government budget.

The complexity of the quota system, the interaction between quotas and tariffs, and the simultaneous Uruguay Round changes in other sectors of the economy make the evaluation of ATC reform difficult. Empirical analysis to quantify the relative magnitude of different impacts becomes necessary. Some of the welfare effects from tariff reduction and quota phase-out that need to be considered are outlined in the following.

o The removal of quantitative restrictions eliminates the basis for quota rents. The latter are passed from exporters to consumers in previously import constrained markets in the form of lower prices. There are also efficiency gains from specialization according to comparative advantage, which in the case of the US, the EU and other quota-constrained countries is likely to imply increasing domestic consumption and reducing production. As the MFA arrangements were motivated by potential adjustment problems within developed importing countries posed by surges of lower cost imports, the shift of labor and capital resources out of the textiles and clothing sector is likely to entail sizeable adjustment costs. Hence, there are advantages and disadvantages to developed importing countries from ATC reform.

o Importers of textiles and clothing that were previously unconstrained, such as Japan, could well experience reductions in welfare from the removal of textiles quotas. Exporters will tend to divert sales to previously constrained markets, possibly resulting in import price increases and a terms-of-trade deterioration in previously unconstrained importing countries.

o The lowering of tariffs applied to textiles and clothing imports will affect the amount of tariff revenues collected by governments. If the demand for imports is very price elastic, such that a reduction in tariffs (to non-zero levels) triggers a large increase in imports, tariff revenue might increase. Otherwise it will decrease.

o For quota-constrained exporting countries, the welfare effects are mixed (Yang, Martin and Yanagishima, 1997). On the one hand, there is the loss of 
quota rent in export markets that were previously constrained. On the other hand, exporters could potentially gain in efficiency to the extent that they shift resources into textiles and clothing, assuming they have an ex post comparative advantage in these industries, which in many cases will be based on their low labor costs. In addition, there is the potential improvement in terms-of-trade on sales of textiles and clothing products to previously unconstrained markets, such as Japan. The size of the terms-of-trade effects will depend largely on the share of sales to previously constrained versus unconstrained markets.

o ATC reforms will also influence the country composition of exports, most likely in the direction of a concentration of suppliers. Whenever textiles and clothing quotas became binding in one country under the MFA, investment was directed to initially unconstrained exporting countries, who then later became constrained also, with investment flowing yet elsewhere. Removing the discriminatory restraints will tend to lead to a reversion to more country concentrated patterns of exports, with many higher cost developing countries, for which the production of textiles and clothing might have been the first stage of the industrialization process, possibly losing out (Whalley, 1999).

o The implications for upstream sectors, like cotton production, are unclear. An overall increase in textiles and clothing production after trade liberalization will also boost the demand for cotton to the benefit of fiber producers. However, textiles and clothing production will shift from industrialized to developing countries, and as the latter often run trade policies that favor domestic fiber producers, cotton producing countries without a significant processing industry might encounter stronger impediments to their export operations than before ATC reform.

\section{The World-Wide Effects of MFA Phase-Out}

A number of analysts have aimed to quantify the impacts of the complex set of trade policy changes contained in the Uruguay Round Agreement. The information requirements for such an undertaking are considerable and analysts have had to compromise between the comprehensiveness of sector and country coverage and the detail of structural and trade policy representation. For example, Haaland and Tollefsen (1994) and Brown, Deardorff, Fox, and Stern (1997) place the emphasis of their CGE analysis on tariff and services trade liberalization and do not model 
the phasing-out of MFA quotas. Their sectoral results contain estimates of the impact of the Uruguay Round on textiles and clothing, but as the central liberalization feature in this sector was not represented, the findings should be interpreted with care. The following discussion concentrates on quantitative analysis that explicitly deals with MFA quota elimination.

The global effects of textiles trade liberalization have been considered and quantified before the ATC was conceived. For example, Trela and Whalley (1990) analyze the removal of quotas and tariffs between Canada, the EU, the USA and 34 supplying developing countries using a static CGE model under assumptions of perfect competition and constant returns to scale. Traded products are assumed to be homogenous. Their analysis is explicitly geared towards the textiles sector by specifying fourteen textiles and clothing categories and one composite other sector in their model. The researchers expect global welfare gains from quota and tariff elimination to total $\$ 23$ billion per year, or 0.16 per cent of world GDP, with the three developed country importers together accounting for about two-thirds of the gains and developing countries for one third. A number of developing countries are expected to be able to increase their exports by several hundred per cent at the expense of production in developed countries. Nevertheless, a few developing countries are expected to face welfare losses from textiles trade liberalization, as the improved access to developed countries markets would in their cases not compensate for the loss in quota rents. These losses would be more widespread and pronounced, if the textiles market liberalization would consist of eliminating quotas, but leaving tariffs unchanged, as assumed by the analysts in a second policy scenario.

In a follow-up study (Trela and Whalley, 1995), the authors expand their CGE model to capture effects related to internal quota-allocation schemes in exporting countries. This is done by distinguishing two types of producers in exporting developing countries: established, high-cost producers that supply restricted export markets, and new and more efficient producers that are confined to supply the domestic market. Removal of MFA restrictions and quota-allocation procedures would allow textiles and clothing production to shift to the most efficient producer, both internationally and domestically. Trela and Whalley estimate that the welfare losses from inefficient quota-allocation schemes exceed those from the country quotas, so that the global benefits of quota and tariff elimination would amount to $\$ 49.7$ billion annually, or 0.34 per cent of global GDP. The benefits of removing the inefficient quota-allocation scheme would mainly accrue to developing country 
exporters, even though some of the efficiency improvements would be passed on to developed country importers in the form of lower prices.

The first quantitative assessments of the Uruguay Round Agreement predicted very substantial impacts from the opening of textiles and clothing markets. Nguyen, Perroni and Wigle (1993) evaluate the implications of the Draft Final Act of the Uruguay Round for nine sectors and ten country groups using a static CGE model. They find that the aggregate welfare gains from textiles quota expansion would exceed those of the scheduled agriculture and service market liberalization and account for $\$ 84.5$ billion per year, or almost 40 per cent of the total Uruguay Round gains. ${ }^{2}$ The welfare gains would fall roughly equally on developed and developing countries. World trade in textiles is expected to increase by six per cent. Large-scale labor market adjustments are predicted, with the country group comprising South Korea, Chinese Taipei, Hong Kong/China, and Singapore expected to see employment in textiles and clothing production increase by more than 80 per cent, while the textiles labor force in Australia and New Zealand, Canada, the USA, and Western Europe is foreseen to contract by 22 to 36 per cent.

Large shares in overall Uruguay Round welfare gains from textiles trade liberalization are also found by other analysts. Using a dynamic CGE model under assumptions of perfect competition and constant returns to scale, Francois, McDonald and Nordström (1994) estimate the global gains from textiles and clothing quota removal to amount to $\$ 47$ billion annually, ${ }^{3}$ which corresponds to 42 per cent of their estimate of total Uruguay Round welfare increases. In a second scenario, in which the authors assume monopolistic competition and increasing returns to scale, the predicted welfare gains from textiles market liberalization are at $\$ 189$ billion more than four times higher than in their first scenario and account for no less than two-thirds of all Uruguay Round gains. Moreover, in the second scenario all countries, including developing countries, see welfare improvements from textiles quota elimination, while developing countries lose in the case of perfect competition and constant returns to scale. This result is due to the greater price elasticity of import demand under monopolistic competition and increasing returns to scale, so that the benefits from improved access of developing countries to

\footnotetext{
${ }^{2}$ In the Nguyen et al. analysis, textiles and clothing are grouped together with furniture into a light industries sector, so that a part of the reported welfare gains from trade liberalisation will be due to improved furniture market access.

${ }^{3}$ The estimates apply to the removal of industrial quotas, which in the authors analysis comprise quotas on Japanese car exports alongside textile and clothing quotas.
} 
developed country markets more easily compensate for the loss of quota rents.

In a subsequent study (Francois, McDonald and Nordström, 1996), the authors use a similar modeling set-up for a different baseline period and a more detailed sectoral and regional breakdown. In addition, they explore alternative linkages between trade, income and capital accumulation. In particular, different assumptions concerning the capital stock (fixed or endogenous) and the savings rate (fixed or endogenous) are considered in order to study longer-term capital accumulation effects that can magnify income gains or losses. The results indicated that incorporation of "full dynamics" (both capital stock and savings rate endogenous) leads to estimates of global welfare gains from textiles and clothing market liberalization that are almost twice as high as those under the assumption of a fixed capital stock and a fixed savings rate.

Yang, Martin and Yanagishima (1997) analyze textiles and clothing market liberalization using the Global Trade Analysis Project (GTAP) CGE model, calibrated on data for the year 1992. They distinguish 10 sectors, including two for textiles and clothing, and 10 regions. Their results suggest that the ATC would account for aggregate annual benefits of $\$ 28.6$ billion, or 38 per cent of all global welfare gains from the Uruguay Round. The authors also report expected terms-of-trade changes due to the phase-out of MFA quotas, which show improvements in export to import price ratios for Australasia, North America and the EU, while Japan and developing countries are expected to see a worsening in their terms-of-trade.

A version of the GTAP model is also used by Hertel, Martin, Yanagishima and Dimaranan (1996) when analyzing the liberalization of manufacturing trade. But their estimates are based on ATC reform in a projected economy of the year 2005. They find that MFA quotas would become more binding over time for virtually all exporters, taking into account projected economic growth, structural changes, and ATC quota growth. The increases in restrictiveness are particularly pronounced for exports of clothing from China, Indonesia, Malaysia and the Philippines. Removing textiles and clothing quotas under these circumstances would leads to global welfare gains of 0.15 per cent of world-GDP, or $\$ 37.3$ billion per year.

Bach, Dimaranan, Hertel and Martin (2000) explicitly compare liberalization scenarios with and without considering projected changes in the economy during the Uruguay Round implementation period. Simulations of MFA removal using the high export tax equivalents for 2005 (Table 1) yield estimates of global welfare gains that are more than 140 per cent higher (in 1992-US\$) than those obtained using export taxes for the year 1992. The differences between simulation results for 
other parts of the Uruguay Round package, such as tariff reform, are much less pronounced, suggesting that economic growth and structural changes in the textiles and clothing sector warrant particular attention by analysts.

Yang (1996) also analyses MFA reform for an economy projected to the year 2005. He first evaluates the impacts of quota acceleration during the ATC transition period, before proceeding to an assessment of MFA quota elimination. He finds that the production and welfare impacts during the three phases of ATC transition are limited. One reason for the small effects might be that the integration requirements are defined in volume terms so that importing countries can minimize their adjustment needs by first integrating product items that are high in volume but low in value (Bagchi, 1994). The global welfare improvement from full elimination of MFA quotas is projected to amount to $\$ 52.9$ billion annually, or 0.22 per cent of global GDP. In a further scenario, the author evaluates the implications of induced technological change on the liberalization outcome and estimates that the benefits of reform would be magnified substantially and would, under his assumptions, lead to welfare gains for all country groups concerned.

Using a static CGE model under constant returns to scale, Harrison, Rutherford and Tarr (1997) estimated the annual benefits of ATC reform to amount to $\$ 16$ billion, or 27 per cent of total Uruguay Round gains. An increasing returns to scale version of their model predicted slightly higher global welfare gains from textiles

Table 1. Share of Exports to Restricted Markets and Export Tax Equivalents, 1992 and 2005

\begin{tabular}{lccccccccccccc}
\hline & \multicolumn{1}{c}{ Textiles } & \multicolumn{1}{c}{ Clothing } \\
\cline { 2 - 13 } & \multicolumn{3}{c}{ Shares (\%) } & Export tax equivalents (\%) & \multicolumn{3}{c}{ Shares (\%) } & Export tax equivalents (\%) \\
\cline { 2 - 13 } & 1992 & 2005 & 1992 & 2005 & 1992 & 2005 & 1992 & 2005 & 1992 & 2005 & 1992 & 2005 \\
\hline Korea & 15 & 14 & 10 & 14 & 10 & 16 & 58 & 54 & 23 & 35 & 19 & 33 \\
Taiwan & 12 & 7 & 8 & 25 & 12 & 28 & 83 & 76 & 19 & 33 & 22 & 39 \\
Hong Kong & 7 & 4 & 7 & 17 & 8 & 22 & 81 & 70 & 17 & 29 & 16 & 32 \\
China & 19 & 12 & 19 & 36 & 27 & 44 & 33 & 20 & 40 & 62 & 36 & 63 \\
Indonesia & 25 & 22 & 13 & 18 & 17 & 26 & 58 & 58 & 46 & 56 & 48 & 64 \\
Malaysia & 21 & 17 & 10 & 16 & 12 & 22 & 47 & 32 & 37 & 52 & 32 & 54 \\
Philippines & 50 & 47 & 9 & 12 & 10 & 24 & 84 & 80 & 33 & 43 & 28 & 48 \\
Thailand & 40 & 32 & 9 & 16 & 13 & 25 & 44 & 33 & 35 & 48 & 36 & 53 \\
Latin America & 50 & 58 & 10 & 5 & 13 & 12 & 89 & 93 & 20 & 19 & 18 & 21 \\
South Asia & 45 & 42 & 19 & 24 & 27 & 36 & 83 & 80 & 40 & 51 & 36 & 53 \\
Other countries & 59 & 66 & 5 & 0 & 6 & 6 & 87 & 94 & 16 & 15 & 10 & 15 \\
\hline
\end{tabular}

Source: Bach et al., 2002. 
and clothing liberalization of $\$ 16.4$ billion, and the simultaneous consideration of dynamic capital accumulation effects resulted in a benefit estimate of \$20.3 billion. Similar to the analysis by Francois et al. (1996), the incorporation of dynamic linkages in the model led to more optimistic estimates concerning the impact of ATC reform on developing countries. Harrison et al. also conducted sensitivity analysis with respect to the elasticities of demand, and found that developing countries would experience higher and more widely spread welfare increases if demand was assumed to be relatively more inelastic, as reductions in import prices would trigger larger demand increases in developed importing countries and higher termsof-trade gains in unconstrained markets. Moreover, larger elasticities of substitution between different export markets would benefit developing countries in the aggregate, but efficient producers, such as China, South Asia, Indonesia, Thailand, and Malaysia, would gain from the possibility of breaking more easily into previously constrained markets at the expense of high-cost producers in Latin America, the Middle East, North Africa, Eastern Europe and the former Soviet Union.

In their study of the impact of global trade policy reform, Chadha, Pratap, Bandyopadhyay, Sachdeva and Kurien (2000) use a CGE model under increasing returns to scale, monopolistic competition and product heterogeneity. They expect modest global welfare improvements of $\$ 6.5$ billion, or 0.02 per cent of worldGDP, from the phase-out of MFA quotas, which corresponds to five per cent of the total Uruguay Round gain. One reason for their relatively low benefits-estimate might be that export tax equivalents of MFA quotas in India, the geographical focus of the Chadha et al. study, have risen significantly over time (Kathuria and Bhardwaj, 1998), so that the effects of removing existing trade barriers would tend to be more pronounced for a base year closer to the implementation deadline.

Diao and Somwaru (2001) stress the impacts of liberalization over time in their analysis. They model ATC reform as a reduction in tariffs by 30-40 per cent and an annual increase in export efficiency by 0.5 per cent over 20 years. They predict that textiles and clothing trade levels after trade policy reform would be 5 to 16 per cent higher than they would have been without trade liberalization, with trade in clothing products increasing twice as fast as textiles trade. Clothing and textiles exports from developing countries would increase, but so would to some extent textiles exports from industrialized countries. This finding hints at the international interrelationships in production patterns with lower prices for clothing stimulating demand in developed countries and exports from developing countries, who in turn increase their imports of capital-intensive textiles products used as inputs for the 
production of labor-intensive clothing. Asian and Middle Eastern exporters are expected to gain world market share, at the expense of producers in Eastern Europe, Latin America, and industrialized countries. As the authors assume that no MFA quota rents exist, the improved resource allocation after trade liberalization leads to welfare gains in all countries. Global benefits are expected to amount to $\$ 88$ billion annually in the short run (Year 5) and $\$ 203$ billion in the long run (Year 20). More than two-thirds of all welfare gains accrue to developing countries.

Recent IMF analysis using the GTAP model covers impacts on labor market and upstream sectors (Lankes 2002). It is estimated that each job saved in a developed country by tariffs and quotas costs about 35 jobs in developing countries. Eliminating MFA quotas and tariffs on textiles and clothing in developed countries would generate employment for as many as 27 million workers in developing countries. Global welfare gains are estimated to amount to $\$ 34.7$ billion per year, with more than two-thirds of the total accruing to developing countries. Some of these gains would be captured by fiber crop producers. For example, cotton exports from sub-Saharan Africa are expected to increase by 9 per cent, or $\$ 132$ million, as a result of textiles and clothing liberalization. The study also evaluates the impact of further liberalization of textiles and clothing trade, including tariff reductions in developing countries, and finds that developing countries would be able to capture almost all the welfare gains from such liberalization efforts.

A major impact on textiles and clothing trade flows during the 1990s has ensued from regional trade agreements, like the Europe Agreements and NAFTA, as well as from the establishment of offshore processing legislation, which enabled firms to circumvent MFA quotas (Brugnoli and Resmini, 1996; Spinanger, 1999). Fouquin, Morand, Avisse, Minvielle and Dumont (2002) quantify the impacts of further regional integration, in addition to analysis of MFA quota elimination. In particular, they simulate the impact of hypothetical free trade areas between the European Union and Mediterranean countries, and between North and Latin American countries. They find that removing the remaining EU tariffs on textiles and clothing imports from Mediterranean countries would boost production of textiles and clothing by 20 per cent and more than 50 per cent, respectively. Clothing exports to the EU would more than double. In terms of welfare effects, the Mediterranean countries would gain $\$ 3$ billion per year compared to a welfare loss under a scenario of MFA quota elimination without regional preferences. Due to trade diversion, Asian exporters, notably China, would lose in exports and economic welfare. Qualitatively similar effects are predicted from the creation of a free trade 
area of the Americas, even though the quantitative impacts are expected to be less pronounced.

\section{Summary of Findings}

The preceding sections surveyed a considerable number of quantitative analyses of ATC reform. The key characteristics and main results of 27 assessments, drawn from 14 different studies, have been discussed and analyzed. The ATC reform simulations rely on differing modeling approaches, base data, and behavioral and structural assumptions, which drive the results. The most salient features of the studies and the main findings are summarized, respectively, in Table 2 and Table 3. It seems a priori impossible to judge which analyst is right or wrong in his or her assessment. In any case, having several estimates derived under different circumstances can make it possible to increase ones confidence about some consistently obtained simulation outcomes, while at the same time help to identify issues that might warrant further analysis.

For example, the modeling results consistently indicate considerable shifts in textiles and clothing production and trade as the ATC is implemented. There is pressure for a large-scale reallocation of resources, with production of textiles and clothing expanding in Asian and other developing countries. In parallel, textiles and clothing production in industrialized countries is expected to contract significantly, while imports of textiles and clothing from developing countries increase.

All the reviewed studies foresee increases in global welfare as a result of a liberalization of trade in textiles and clothing. But the estimates of welfare gains show considerable variation, with expected annual global benefits ranging from $\$$ 6.5 billion to $\$ 324$ billion, or 0.02 per cent to 1.49 per cent of world GDP. Some studies predict ATC reform to account for up to two-thirds of all gains from the Uruguay Round, while others put the contribution of textiles and clothing liberalization at merely 5 per cent. There is similar discrepancy with respect to the distribution of welfare gains. A number of analysts see developing countries as the main beneficiaries of ATC reform, while others expect them in the aggregate to lose from the policy changes. There is also variation in the direction of expected welfare impacts at the level of many individual countries.

The diversity in results seems to a considerable extent be due to differing structural features in the available studies, even though the choice of the particular base year 
Table $2^{*}$ Structural characteristics of ATC reform studies using CGE models

\begin{tabular}{|c|c|c|c|c|c|c|c|c|c|}
\hline Study & & $\begin{array}{l}\text { Base } \\
\text { year }\end{array}$ & $\begin{array}{l}\text { MFA quota } \\
\text { representation }\end{array}$ & Dynamics & Competition & Imports & $\begin{array}{l}\text { Sectors } \\
(\mathrm{T} \& \mathrm{C})\end{array}$ & Regions & Policy reform scenario \\
\hline \multirow[t]{2}{*}{ Trela \& Whalley (1990) } & $\mathrm{a}$ & 1986 & Bilateral quotas & Static & Perfect & Homogeneous & $15(14)$ & 37 & Quota \& tariff elimination \\
\hline & $\mathrm{b}$ & 1986 & Bilateral quotas & Static & Perfect & Homogeneous & $15(14)$ & 37 & Quota elimination \\
\hline Nguyen et al. (1993) & & 1986 & Bilateral quotas & Static & Perfect & Heterogeneous & $9(1)$ & 10 & Exp. of quotas by a factor of 4 \\
\hline \multirow[t]{4}{*}{ Francois et al. (1994) } & $\mathrm{a}$ & 1990 & Bilateral quotas & Dynamic & Perfect & Heterogeneous & $15(2)$ & 9 & Quota elimination \& tariff reduction \\
\hline & $\mathrm{b}$ & 1990 & Bilateral quotas & Dynamic & Monop. & Heterogeneous & $15(2)$ & 9 & Quota elimination \& tariff reduction \\
\hline & $\mathrm{c}$ & 2005 & Bilateral quotas & Dynamic & Perfect & Heterogeneous & $15(2)$ & 9 & Quota elimination \& tariff reduction \\
\hline & $\mathrm{d}$ & 2005 & Bilateral quotas & Dynamic & Monop. & Heterogeneous & $15(2)$ & 9 & Quota elimination \& tariff reduction \\
\hline \multirow[t]{2}{*}{ Trela \& Whalley (1995) } & a & 1986 & Bilateral quotas & Static & Perfect & Homogeneous & $15(14)$ & 37 & Quota \& tariff elimination \\
\hline & $\mathrm{b}$ & 1986 & Bilateral quotas & Static & Perfect & Homogeneous & $15(14)$ & 37 & Quota elimination \\
\hline \multirow[t]{6}{*}{ Francois et al. (1996) } & $\mathrm{a}$ & 1992 & Export tax equivalents & Static & Perfect & Heterogeneous & $19(2)$ & 13 & Quota elimination \& tariff reduction \\
\hline & $\mathrm{b}$ & 1992 & Export tax equivalents & Semi-dyn. & Perfect & Heterogeneous & $19(2)$ & 13 & Quota elimination \& tariff reduction \\
\hline & $\mathrm{c}$ & 1992 & Export tax equivalents & Dynamic & Perfect & Heterogeneous & $19(2)$ & 13 & Quota elimination \& tariff reduction \\
\hline & $\mathrm{d}$ & 1992 & Export tax equivalents & Static & Monop. & Heterogeneous & $19(2)$ & 13 & Quota elimination \& tariff reduction \\
\hline & e & 1992 & Export tax equivalents & Semi-dyn. & Monop. & Heterogeneous & $19(2)$ & 13 & Quota elimination \& tariff reduction \\
\hline & $\mathrm{f}$ & 1992 & Export tax equivalents & Dynamic & Monop. & Heterogeneous & $19(2)$ & 13 & Quota elimination \& tariff reduction \\
\hline Hertel et al. (1996) & & 1992 & Export tax equivalents & Static & Perfect & Heterogeneous & $10(2)$ & 15 & Quota elimination \\
\hline Yang (1996) & & 2005 & Export tax equivalents & Static & Perfect & Heterogeneous & $6(2)$ & 15 & Quota elimination \\
\hline \multirow[t]{3}{*}{ Harrison et al. (1997) } & a & 1994 & Export tax equivalents & Static & Perfect & Heterogeneous & $22(2)$ & 24 & Quota elimination \& tariff reduction \\
\hline & $b$ & 1994 & Export tax equivalents & Static & Monop. & Heterogeneous & $22(2)$ & 24 & Quota elimination \& tariff reduction \\
\hline & c & 1994 & Export tax equivalents & Dynamic & Monop. & Heterogeneous & $22(2)$ & 24 & Quota elimination \& tariff reduction \\
\hline Yang et al. (1997) & & 1992 & Export tax equivalents & Static & Perfect & Heterogeneous & $10(2)$ & 10 & Quota elimination \& tariff reduction \\
\hline \multirow[t]{2}{*}{ Bach et al. (2000) } & a & 1992 & Export tax equivalents & Static & Perfect & Heterogeneous & $8(2)$ & 13 & Quota elimination \\
\hline & $b$ & 2005 & Export tax equivalents & Static & Perfect & Heterogeneous & $8(2)$ & 13 & Quota elimination \\
\hline Chadha et al. (2000) & & 1995 & Export tax equivalents & Static & Monop. & Heterogeneous & $23(2)$ & 7 & Quota elimination \\
\hline Diao \& Somwaru (2001) & & 1997 & Export inefficiency & Dynamic & Perfect & Heterogeneous & $7(2)$ & 13 & Export efficiency incr. \& tariff reduction \\
\hline Fouquin et al. (2002) & & 1997 & Export tax equivalents & Static & Perfect & Heterogeneous & $7(2)$ & 13 & Quota elimination \\
\hline Lankes (2002) & & 1997 & Export tax equivalents & Static & Perfect & Heterogeneous & $7(3)$ & 17 & Quota \& tariff elimin. in industrial. c'tries. \\
\hline
\end{tabular}


Table 3. Estimates of annual welfare gains from ATC reform (base year billion US\$)

\begin{tabular}{|c|c|c|c|c|c|c|c|c|c|c|c|}
\hline \multirow[b]{2}{*}{ Study } & & \multicolumn{2}{|c|}{$\begin{array}{c}\text { Global welfare } \\
\text { gains }\end{array}$} & \multicolumn{3}{|c|}{ Developed countries } & \multicolumn{3}{|c|}{ Developing countries } & \multirow{2}{*}{$\begin{array}{l}\text { Share of UR } \\
\text { (\% of total } \\
\text { UR gains) }\end{array}$} & \multirow[t]{2}{*}{ Comment } \\
\hline & & $\begin{array}{l}\text { (\% of } \\
\text { GDP) }\end{array}$ & $(\$ \mathrm{bn})$ & $\begin{array}{l}(\% \text { of } \\
\text { total) }\end{array}$ & $\begin{array}{l}\text { E15 } \\
\text { (\$ bn) }\end{array}$ & $\begin{array}{l}\text { USA } \\
(\$ \text { bn })\end{array}$ & $\begin{array}{l}\text { (\% of } \\
\text { total) }\end{array}$ & $\begin{array}{l}\text { CHN } \\
(\$ \text { bn })\end{array}$ & $\begin{array}{l}\text { IND } \\
(\$ \text { bn })\end{array}$ & & \\
\hline \multirow[t]{2}{*}{ Trela \& Whalley (1990) } & $\mathrm{a}$ & $0.16 \%$ & 23.4 & $65 \%$ & 2.2 & 12.3 & $35 \%$ & 1.8 & 0.1 & & \\
\hline & $\mathrm{b}$ & $0.15 \%$ & 21.9 & $87 \%$ & 3.0 & 15.0 & $13 \%$ & 0.9 & -0.1 & & \\
\hline Nguyen et al. (1993). & & $0.58 \%$ & 84.5 & $51 \%$ & 17.2 & 21.6 & $49 \%$ & & & $40 \%$ & \\
\hline \multirow[t]{4}{*}{ Francois et al. (1994) } & a & $0.22 \%$ & 47.0 & $116 \%$ & 26.4 & 23.6 & $-16 \%$ & -1.0 & & $42 \%$ & Dynamics through endogenous capital stock \\
\hline & $\mathrm{b}$ & $0.87 \%$ & 189.0 & $81 \%$ & 70.7 & 62.9 & $19 \%$ & 1.6 & & $65 \%$ & Dynamics through endogenous capital stock \\
\hline & $\mathrm{c}$ & $0.33 \%$ & 71.0 & $124 \%$ & 42.9 & 38.4 & $-24 \%$ & -3.5 & & $39 \%$ & Dynamics \& 2005 projected economy \\
\hline & $\mathrm{d}$ & $1.49 \%$ & 324.0 & $77 \%$ & 115.1 & 102.3 & $23 \%$ & 5.4 & & $64 \%$ & Dynamics \& 2005 projected economy \\
\hline \multirow[t]{2}{*}{ Trela \& Whalley (1995) } & a & $0.34 \%$ & 49.7 & $43 \%$ & 3.7 & 16.4 & $57 \%$ & 1.9 & 0.5 & & Capturing effects of inefficient quota-allocation schemes. \\
\hline & $\mathrm{b}$ & $0.33 \%$ & 48.3 & $52 \%$ & 4.7 & 19.2 & $48 \%$ & 1.2 & 0.3 & & Capturing effects of inefficient quota-allocation schemes. \\
\hline \multirow[t]{6}{*}{ Francois et al. (1996) } & a & $0.08 \%$ & 18.4 & $73 \%$ & 5.9 & 7.1 & $27 \%$ & 3.3 & & $46 \%$ & \\
\hline & $\mathrm{b}$ & $0.12 \%$ & 28.4 & $72 \%$ & 8.6 & 10.8 & $28 \%$ & 5.4 & & $44 \%$ & Endogenous capital stock \& fixed savings rate \\
\hline & c & $0.15 \%$ & 35.7 & $64 \%$ & 9.4 & 11.9 & $36 \%$ & 5.9 & & $35 \%$ & Endogenous savings rate \& end. capital stock. \\
\hline & $\mathrm{d}$ & $0.24 \%$ & 58.7 & $39 \%$ & 10.3 & 11.7 & $61 \%$ & 9.4 & & $59 \%$ & \\
\hline & $\mathrm{e}$ & $0.49 \%$ & 118.1 & $32 \%$ & 17.3 & 19.2 & $68 \%$ & 19.0 & & $61 \%$ & Endogenous capital stock \& fixed savings rate \\
\hline & $\mathrm{f}$ & $0.44 \%$ & 107.7 & $41 \%$ & 18.5 & 22.6 & $59 \%$ & 11.2 & & $50 \%$ & Endogenous savings rate $\&$ end. capital stock. \\
\hline Hertel et al. (1996) & & $0.15 \%$ & 37.3 & $132 \%$ & 24.9 & & $-32 \%$ & 5.9 & & $14 \%$ & Based on 2005 projected economy \\
\hline Yang (1996) & & $0.22 \%$ & 52.9 & $131 \%$ & 30.7 & & $-31 \%$ & 5.1 & & $49 \%$ & \\
\hline \multirow[t]{3}{*}{ Harrison et al. (1997) } & a & $0.07 \%$ & 16.0 & $114 \%$ & 7.6 & 10.1 & $-14 \%$ & 0.9 & & $27 \%$ & \\
\hline & $\mathrm{b}$ & $0.07 \%$ & 16.4 & $109 \%$ & 7.6 & 10.0 & $-9 \%$ & 1.0 & & $17 \%$ & \\
\hline & $\mathrm{c}$ & $0.08 \%$ & 20.3 & $83 \%$ & 7.8 & 9.2 & $17 \%$ & 1.7 & & $12 \%$ & Dynamics through endogenous capital stock \\
\hline Yang et al. (1997) & & $0.12 \%$ & 28.6 & $104 \%$ & 13.5 & & $-4 \%$ & 5.6 & & $38 \%$ & \\
\hline \multirow[t]{2}{*}{ Bach et al. (2000) } & a & $0.07 \%$ & 16.2 & $111 \%$ & 8.1 & & $-11 \%$ & 1.9 & 1.4 & $30 \%$ & \\
\hline & $\mathrm{b}$ & $0.16 \%$ & 38.9 & $120 \%$ & 23.3 & & $-20 \%$ & 7.2 & 1.9 & $38 \%$ & Based on 2005 projected economy \\
\hline Chadha et al. (2000) & & $0.02 \%$ & 6.5 & $63 \%$ & & 4.4 & $37 \%$ & 0.6 & 1.9 & $5 \%$ & \\
\hline Diao \& Somwaru (2001) & & $0.68 \%$ & 203.0 & $28 \%$ & 19.4 & & $72 \%$ & 23.7 & 10.8 & & Welfare effects after year 20 \\
\hline Fouquin et al. (2002) & & $0.03 \%$ & 9.8 & & 1.5 & & & 6.0 & 4.1 & & \\
\hline Lankes (2002) & & $0.12 \%$ & 34.7 & $31 \%$ & & & $69 \%$ & & & & \\
\hline
\end{tabular}

Source: 
and the estimates of the restrictiveness of MFA quotas also play a significant role. The different combinations of assumptions concerning issues such as perfect versus imperfect competition or homogeneous versus heterogeneous imports can be helpful for analysts and policy makers to choose and work with the assessment that best matches their prior knowledge about the textiles and clothing economy. Yet, the important impact of particular assumptions on the modeling results also highlights the need to improve the motivation and foundation of specific study characteristics through empirical analysis in order to gain credibility for a particular studys set-up and results.

In this context of uncertainty regarding the reform outcome, it is striking that developing countries have consistently been supporting the removal of the MFA. But, as some of the quantitative studies show, this stance is understandable in a dynamic world where capital accumulation effects are taken into account and the fact that inefficient quota-allocation schemes can lead to a dissipation of quota rents over time. Under these circumstances, elimination of the MFA might make it possible for developing countries to seize upon their comparative advantage in textiles and clothing and increase their export revenues and incomes. Yet, further disaggregated analysis of the impacts of textiles liberalization on developing countries, including smaller and potentially vulnerable textiles and clothing producers, could yield valuable background information that might enable analysts to improve their policy advise.

A second remarkable result from the empirical studies is that the EU and the USA are again and again expected to experience substantial increases in welfare from ATC reform, while these countries had been among the initiators of the MFA in the first place. The optimistic modeling results seem partly due to the implicit assumption that resources that are released from some activity can switch to another one without major disruption. In other words, any potential short or medium-term adjustment problem is assumed away. There are very few studies, such as De Melo and Tarr (1990), that try to incorporate adjustment costs into their assessment, and this is then often done in a rather ad hoc way. While substantial welfare gains for most developed countries from lower consumer prices and more efficient resource allocation seem likely in the longer run, potential adjustment problems following MFA phase-out are an important policy consideration and might warrant further analysis.

Even though the findings in individual studies vary, there are some policy implications that emerge consistently from the quantitative literature on ATC 
reform. For example, the pressure that developed country producers are likely to face from increased imports originating in developing countries might lead to demands by interest groups to implement measures that ease the hardship of developed countries textiles and clothing industries. Yet, the substantial welfare gains from ATC reform projected for the EU and the USA should remind policy makers in these countries about the losses in free trade benefits if new protectionist measures, such as anti-dumping duties, would be put into place. Other structural policies, including those fostering technological innovation or staff re-training, are likely to be more efficient in helping domestic textiles and clothing industries adjust to the new economic environment. Another policy implication concerns the increased need for developing aid. The results from the quantitative studies point to the likely consolidation among developing country exporters. Large low cost producers, notably China and India, will gain in world market share at the expense of smaller developing countries. Some of the latter might even see their textiles and clothing industries vanish completely if they lose their quota-protected access to developed country markets and have to compete openly. In this context, additional development assistance seems warranted to help affected countries prepare for the post-MFA period and diversify out of inefficient textiles and clothing production.

\section{Acknowledgement}

The author would like to thank an anonymous reference and the Editor their constructive comments that have helped to improve the analysis. Any remainging errors are the author's responsibility.

Received 16 May 2003, Accepted 4 November 2003

\section{References}

Bach, C.F., B. Dimaranan, T. Hertel, and W. Martin, 2000. "Market Growth, Structural Change, and the Gains from the Uruguay Round." Review of International Economics 8(2): 295-310.

Bagchi, S., 1994. "The Integration of the Textile Trade in GATT." Journal of World Trade 28(6): 31-42.

Brown, D.K., A.V. Deardorff, A.K. Fox, and R.M. Stern, 1996. "The Liberalization of Services Trade: Potential Impacts in the Aftermath of the Uruguay Round." In: Martin, W., and L.A. Winters (editors), The Uruguay Round and the Developing 
Countries. Cambridge: Cambridge University Press; pp. 183-215.

Brugnoli, A., and L. Resmini, 1996. "Textiles and Clothing Trade: Trends and Development after the Europe Agreements and the Uruguay Round." Paper presented at the third European Community Studies Association Conference on 'The European Union in a Changing World'. Brussels.

Chadha, R., D. Pratap, S. Bandyopadhyay, P. Sachdeva, and B. Kurien, 2000. The Impact of Changing Global Trade Policies on India. Sanei Project Report. New Delhi: National Council of Applied Economic Research.

De Melo, J., and D. Tarr, 1990. "Welfare Costs of U.S. Quotas in Textiles, Steel and Autos." Review of Economics and Statistics 72: 489-497.

Diao, X., and A. Somwaru, 2001. "Impact of MFA Phase-Out on the World Economy: An Intertemporal, Global General Equilibrium Analysis." TMD Discussion Paper No. 79. Washington, D.C.: International Food Policy Research Institute.

Elbehri, A., T. Hertel, and W. Martin, 2003. "Estimating the Impact of WTO and Domestic Reforms on the Indian Cotton and Textile Sectors: A General Equilibrium Approach." Review of Development Economics 7.

Fouquin, M., P. Morand, R. Avisse, G. Minvielle, and P. Dumont, 2002. "Mondialisation et Régionalisation : Le Cas des Industries du Textile et de l'Habillement." Working Paper 2002-08. Paris: Centre d'Etudes Prospectives et d'Informations Internationales.

Francois, J.F., H.H. Glismann, and D. Spinanger, 2000. "The Cost of EU Trade Protection in Textiles and Clothing.” Working Paper No. 997. Kiel: Kiel Institute of World Economics.

Francois, J.F., B. McDonald, and H. Nordström, 1994. "The Uruguay Round: A Global General Equilibrium Assessment.” Discussion Paper No. 1067. London: Centre for Economic Policy Research.

Francois, J.F., B. McDonald, and H. Nordström, 1996. "The Uruguay Round: A Numerically Based Qualitative Assessment.” In: Martin, W., and L.A. Winters (editors), The Uruguay Round and the Developing Countries. Cambridge: Cambridge University Press; pp. 183-215.

Francois, J.F., and D. Spinanger, 2000. "Hong Kongs Textile and Clothing Industry: The Impact of Quotas, the UR and Chinas WTO Accession.” Working Paper. Kiel: Kiel Institute of World Economics.

Francois, J.F., and D. Spinanger, 2002. "Greater China's Accession to the WTO: Implications for International Trade/Production and for Hong Kong." Paper presented at the Fifth Annual Conference on Global Economic Analysis. Taipei, Taiwan.

Goto, J., 1989. "The Multifibre Arrangement and Its Effects on Developing Countries." World Bank Research Observer 4: 203-227.

Haaland, J.I., and T.C. Tollefsen, 1994. "The Uruguay Round and Trade in Manufactures and Services: General Equilibrium Simulations of Production, Trade and Welfare Effects of Liberalization.” Discussion Paper No. 1008. London: Centre for Economic Policy Research.

Hamilton, C.B. (editor), 1990. Textiles and Trade and the Developing Countries: 
Eliminating the Multi-Fiber Arrangement in the 1990s. Washington, D.C.: The World Bank.

Hanson, K.A., and K.A. Reinert, 1997. "The Distributional Effects of U.S. Textile and Apparel Protection.” International Economic Journal 11(3): 1-12.

Harrison, G.W., T.F. Rutherford, and D.G. Tarr, 1997. "Quantifying the Uruguay Round." Economic Journal 107: 1405-1430.

Hertel, T.W., W. Martin, K. Yanagishima, and B. Dimaranan, 1996. "Liberalizing Manufactures Trade in a Changing World Economy." In: Martin, W., and L.A. Winters (editors), The Uruguay Round and the Developing Countries. Cambridge: Cambridge University Press; pp. 183-215.

Ianchovichina, E., W. Martin, and E. Fukase, 2000. "Assessing the Implications of Merchandise Trade Liberalization in Chinas Accession to WTO." Paper presented to the Roundtable on Chinas Accession to the WTO sponsored by the Chinese Economic Society and the World Bank. Pudong/Shanghai.

Kathuria, S., and A. Bhardwaj, 1998. "Export Quotas and Policy Constraints in the Indian Textile and Garment Industries." Policy Research Working Paper No. 2012. Washington, D.C.: The World Bank.

Krishna, K., R. Erzan, and L. Tan, 1994. "Rent Sharing in the Multi-Fiber Arrangement: Theory and Evidence from US Apparel Imports from Hong Kong." Review of International Economics 2(1): 62-73.

Lankes, H.P., 2002. "Market Access for Developing Country Exports." Finance \& Development (September): 8-13.

Nguyen, T.T., C. Perroni, and R.M. Wigle, 1993. "An Evaluation of the Draft Final Act of the Uruguay Round." Economic Journal 103: 1540-1549.

OECD (Organisation for Economic Co-operation and Development), 2003. "Liberalizing Trade in Textiles and Clothing: A Survey of Quantitative Studies." Document TD/ TC/WP(2003)2/Final, Paris.

Pelzman, J., 1983. "Economic Costs of Tariffs and Quotas on Textile and Apparel Products Imported into the United States: A Survey of the Literature and Implications for Policies." Weltwirtschaftliches Archiv 119(3): 523-542.

Reinert, K.A., 1993. "Textile and Apparel Protection in the United States: A General Equilibrium Analysis." World Economy 16: 359-376.

Schöppenau P.v., J. Egerer, P. Brenton, and C. Buelens, 2002. Die Auswirkungen der ATCLiberalisierung auf die Deutsche Textilwirtschaft. Project report, European Public Policy Advisers \& Centre for European Policy Studies, Brussels.

Spinanger, D., 1991. "Experiences with Liberalization Policies: The Case of Textiles." European Economic Review 35: 543-551.

Spinanger, D., 1999. "Textiles Beyond the MFA Phase-Out." World Economy 22(4): 455476.

Trela, I. and J. Whalley, 1990. "Global Effects of Developed Country Trade Restrictions on Textiles and Apparel." Economic Journal 100: 1190-1205.

Trela, I. and J. Whalley, 1995. "Internal Quota-Allocation Schemes and the Costs of the 
MFA.” Review of International Economics 3(3): 284-306.

Walmsley, T.L., and T.W. Hertel, 2000. "China's Accession to the WTO: Timing is Everything." GTAP Working Paper No. 13. West Lafayette/Indiana: Center for Global Trade Analysis.

Whalley, J., 1999. "Notes on Textiles and Apparel in the Next Trade Round." Paper presented at the Harvard University Conference on 'Developing Countries in the Next WTO Trade Round'. Cambridge/Massachusetts.

Yang, Y., 1994. "The Impact of MFA Phasing Out on World Clothing and Textile Markets." Journal of Development Studies 30(3): 892-915.

Yang, Y., 1996. Prospects for the Textile and Clothing Sector of the ESCAP Region in the Post-Uruguay Round Context. Studies in Trade and Investment No. 17. New York: United Nations Economic and Social Commission for Asia and the Pacific.

Yang, Y., W. Martin, and K. Yanagishima, 1997. "Evaluating the Benefits of Abolishing the MFA in the Uruguay Round Package," in Hertel, T. (editor), Global Trade Analysis: Modeling and Applications. Cambridge, New York and Melbourne: Cambridge University Press.

Yang, Y., and C. Zhong, 1998. "China's Textile and Clothing Exports in a Changing World Economy.” Developing Economies 36(1): 3-23. 